\title{
Progress on the fossil Xanthoidea MacLeay, 1838 (Decapoda, Brachyura)
}

\author{
Carrie E. Schweitzer \\ Department of Geology, 'Kent State University, Stark Campus, 6000 Frank Ave. NW, Canton, Ohio 44720, \\ USA
}

Keywords: Decapoda, Brachyura, Xanthoidea, Xanthidae, proxy characters

\begin{abstract}
Identification and utilization of proxy characters in extant families has been accomplished with success for fossil members of the Calappidae, Hepatidae, Necrocarcinidae, Matutidae, and Hexapodidae. The fossil and extant Raninidae have been revised using primarily hard-part morphology preserved in the fossil record although formal designation of "proxy characters" has not occurred. Hard-part characters can also be used to differentiate among members of the Atelecyclidae and the Cheiragonidae. Thus, the method of using proxy characters is demonstrably suitable for application to a difficult group like the Xanthoidea.
\end{abstract}

\section{Introduction}

Fossil Xanthoidea have traditionally been referred to the Xanthidae MacLeay, 1838 senso lato, and occasionally arrayed within the various xanthid subfamilies (Rathbun, 1930; Glaessner, 1969). Over the past four decades, biologists have separated the extant Xanthoidea into several families. At the time of this writing, twelve extant families are widely recognised (Martin \& Davis, 2001; Ng \& Liao, 2002; Schweitzer, in press), and an additional two extinct families are known (Schweitzer, in press) (Table 1). Extant xanthoids are diagnosed based upon features of the eyes, antennae, mouthparts, gonopores, gonopods, and the degree of fusion of the articles of the first pereiopods, the abdomen, and the sternum (Guinot, 1979; Davie, 2002). Most of these features rarely, if ever, fossilize. Thus, paleontologists are forced to rely primarily upon features of the dorsal carapace. In some serendipitous cases, the entire cheliped, sternum, and abdomen are preserved and can be used as well. Some notable recent works by neontologists do provide dorsal carapace information (Ng, 1998; Davie, 2002) and are thus quite useful to the paleontologist as is the work on the sternum, abdomen, and pereiopods by Guinot $(1968 \mathrm{a}, \mathrm{b}, 1978,1979)$ and others.

Because many xanthoid families are superficially and amazingly similar in terms of dorsal carapace morphology, it can be very difficult to place fossil xanthoids within a family. In addition, the dorsal carapace morphology of members of subfamilies within the same family are often extremely divergent, as in the Goneplacidae, Panopeidae, and Pilumnidae (Davie, 2002; Karasawa \& Kato, in press). Thus, the framing of a family-level diagnosis for these xanthoid families based upon features of the dorsal carapace is nearly impossible.

The application of the work of Guinot (1968a, b, 1978, 1979) on the sternal, abdominal, and first pereiopod morphology of brachyurans has been of great assistance in family placement of fossil xanthoids. For example, members of the Carpiliidae have been recognized in the fossil record based upon the merus of the major cheliped being fused to the basis-ischium and the direct articulation of the merus and coxa (Guinot, 1968a, b). Differences in the degree of fusion of male abdominal somites has been quite useful in placing fossils into the Hexapodidae and Goneplacidae and promises to be useful for the Panopeidae and Pilumnidae as well (Schweitzer \& Feldmann, 2001; Davie, 2002; Karasawa \& Kato, in press).

Even though articles of the pereiopods and elements of the sternum and abdomen are useful, they are much less commonly preserved than the dorsal 
carapace. In addition, they are often incompletely preserved. Thus, important features, such as whether the eighth sternite is visible in dorsal view or not, may not be observable. The latter feature is important for classifying goneplacids and pilumnids (Davie, 2002; Karasawa \& Kato, in press). Consequently, it is important to try to identify a suite of characters primarily of the dorsal carapace, but including some features of the chelipeds, sternum, and abdomen, that are diagnostic for a particular family. These suites of dorsal carapace characters are called proxy characters (Schweitzer \& Feldmann, 2000; Schweitzer, in press). The term "proxy character' is used because these characters track with the soft-part morphology that neontologists typically use. These proxy characters may be found in both extant and fossil members of a taxon, but they are seldom if ever noted by neontologists when decapods are described.

Definition, choice, and use of proxy characters is relatively straightforward. Members of extant decapod families, as defined by biologists based upon soft-part morphology, serology, genetics, larvae, and sperm, are examined either in museum collections or from illustrations in biological literature. Then, distinctive features of the dorsal carapace can be identified that characterize most or all members of the group. In many cases, several characters must be used together as a suite. Often there is not one single dorsal carapace character that identifies members of a family; if there was, classification of the Xanthoidea would not be so difficult! The types of characters that have proven to be useful thus far are various length/width ratios; the shape, length, and ornament of the front and anterolateral margins; the angle of the posterolateral margin to the posterior margin; the relative size of carapace regions; the shape and ornament of the orbits; and the position of maximum width of the carapace.

Identification and utilization of proxy characters in extant families has been accomplished with success for fossil members of the Calappidae, Hepatidae, Necrocarcinidae, Matutidae, and Hexapodidae (Schweitzer \& Feldmann, 2000, 2001). Tucker (1998) revised the fossil and extant Raninidae de Haan, 1839, using primarily hard-part morphology preservable in the fossil record although she did not designate proxy characters. Hard-part characters can also be used to differentiate among members of the Atelecyclidae Ortmann, 1893 and the Cheiragonidae Ortmann, 1893 (Schweitzer \& Salva, 2000). Thus, the method is demonstrably suitable for application to a difficult group like the Xanthoidea.

\section{Examples}

The Carpiliidae are clearly recognizable if the elements of the first pereiopods are preserved; even if they are not, the smooth, vaulted carapace; long, convex anterolateral margins; lobate front; narrow posterior margin; posterolateral to posterior margin angle of 25-30 degrees; and fused male abdominal somites 3-5 are diagnostic for the family (Schweitzer, in press). Although there are certainly other smooth, xanthoid decapods in the fossil record, this entire suite of characters is diagnostic only for the Carpiliidae and not for other smooth xanthoids.

Fossil Pseudoziidae are not easily distinguished from carpiliids; however, several features can be used to differentiate the two families. Pseudoziids have smooth carapaces; short anterolateral margins; a posterolateral to posterior margin angle of 40-45 degrees; a broad posterior margin; an íncompletely fused merus and basis-ischium, and no fusion of abdominal somites (Schweitzer, in press).

Members of Via's (1959) subfamily Zanthopsinae ( $=$ Xanthopsinae) have often been placed within the Carpiliidae (Schweitzer, 2000); however, they are morphologically distinct. The merus is not fused to the basis-ischium, and the merus does not articulate directly with the coxa; thus, they are easily excluded from the Carpiliidae. If the chelipeds are not preserved, zanthopsines may be recognized because they have a relatively smooth carapace that is not separated into distinctive regions; shallow grooves; a tightly convex anterolateral margin; a quadri-lobed front; and fused male abdominal somites (Schweitzer, in press). They form a distinctive group united by these morphological features.

Several fossil genera cannot be accommodated by any known family; a new family has been erected to contain them (Schweitzer, in press). Palaeoxanthopsis Beurlen, 1958, Verrucoides Vega et al., 
2001, and two new genera are all characterized by exhibiting a broad carapace; extremely deep, Vshaped grooves separating the gastric and branchial regions; large nodes on the carapace regions; a long anterolateral margin with 4 or 5 pronounced spines; and a last anterolateral spine that is especially long and directed laterally or posterolaterally. These features are quite distinct from any other known xanthoid; thus, a new family has been erected to contain these genera (Schweitzer, in press).

Members of the Hexapodidae are recognized by their rectangular carapace that is widest distally; a bi-lobed rostrum that extends beyond the orbits; a fronto-orbital width that partially occupies the entire frontal margin of the carapace; fused male abdominal somites; and sternite and pereiopod 5 lost (Schweitzer \& Feldmann, 2001). These features can permit hexapodids to be distinguished from pinnotherids and some goneplacids which also have small, rectangular carapaces.

Those are the success stories. However, there are other families that pose major problems for palaeontologists. Within the Goneplacidae, there are several dorsal carapace morphologies, all of which are quite different from one another (Schweitzer, 2000; Davie, 2002; Karasawa \& Kato, in press). Currently, Karasawa and Kato are working on the phylogeny of this family as well as attempting to discern features that can be used to distinguish members of each constituent subfamily. It appears that within the Goneplacidae, the nature of the male abdomen and whether or not the male abdomen covers sternite 8 will be important at the subfamily level (Tucker \& Feldmann, 1990; Davie, 2002; Karasawa \& Kato, in press). Within the Panopeidae, there is similarly a vast range of dorsal carapace morphology, and within that family, the position of the male gonopore ranges from coxal to coxalsternal (Davie, 2002). In addition, the features of the dorsal carapace and the gonopores in the panopeids overlap with some other families of xanthids. Thus, placement of fossils into the Panopeidae is currently extremely difficult. Similarly, the Pilumnidae is a difficult family for palaeontologists. The dorsal carapace ranges from xanthid-like (sensu stricto) to ovate to bizarrely produced rostrally into a bi-pronged extension (Davie, 2002). Any dorsal carapace diagnosis for the pilumnids would need to take into account these vastly divergent morphologies.

Within those families that have divergent dorsal carapace morphologies, usually members with each distinctive morphology are placed within the same subfamily of the family. Thus, at least for the Goneplacidae, Panopeidae, and Pilumnidae, it appears that proxy characters will need to be developed at the subfamily, not family, level. Each subfamily would then have to be considered when working with these families. This greatly complicates the work, as the number of recognized subfamilies within a family varies widely, depending on the author, and because many authors consider some subfamilies to be distinct families while others maintain them as subfamilies. For example, $\mathrm{Ng} \&$ Liao (2002) considered the Pseudoziidae to be a distinct family, while Davie (2002) considered it to be a subfamily of the Goneplacidae. Davie (2002) considered the Eumedonidae to be a subfamily of the Piluminidae, while Martin \& Davis (2001) maintained it as a separate family. Clearly, working with xanthoids is anything but simple.

\section{Implications}

With all of these complications and difficulties, why not just refer problematic xanthoids to the Goneplacidae or Xanthidae sensu lato as has been done in the past? I have done this myself, for example, with the problematic genera Amydrocarcinus Schweitzer et al, 2002 and Lobonotus A. Milne Edwards, 1864. I think, however, that it is time to tackle these difficult fossil xanthoids, because these fossils have manifold implications for the history of brachyuran evolution, not to mention for the ongoing revision of the Decapoda volume of the Treatise on Invertebrate Paleontology.

Currently, we do not have good constraints on the origin of the Xanthoidea and the subsequent radiation of this robust superfamily. As of this writing, only the Goneplacidae and possibly the Hexapodidae have confirmed Cretaceous records; two genera formerly referred to the Xanthidae, Etyus Mantell, 1822, and Xanthosia Bell, 1863, have been referred to the Etyidae Guinot \& Tavares, 2001, and are considered to be primitive podotrematous 
Table 1. List of xanthoid families, recognized at the time of this writing (March, 2003)

\begin{tabular}{ll}
\hline Family & Geologic Range \\
\hline *Carpiliidae Ortmann, 1893 & $\begin{array}{l}\text { Eocene-Recent } \\
\text { unresolved }\end{array}$ \\
Eriphídae MacLeay, 1838 (= Menippidae Ortmann, 1893) & \\
Eumedonidae Dana, 1853 (considered by Ng \& Clark (2000) & unknown \\
and Davie (2002) as a subfamily of the Pilumnidae & Cretaceous - Recent \\
*Goneplacidae MacLeay, 1838 & Cretaceous?; Paleocene - Recent \\
*Hexapodidae Miers, 1886 & Eocene - Recent \\
*Panopeidae Ortmann, 1893 & Eocene - Recent \\
*Pilumnidae Samouelle, 1819 & unknown \\
Platyxanthidae Guinot, 1977 & Eocene - Récent \\
*Pseudoziidae Alcock, 1898 & unknown \\
Pseudorhombilidae Alcock, 1900* & Míocene - recent \\
*Trapeziìdae Miers, 1886 & unresolved \\
*Xanthídae MacLeay, 1838 & Paleocene - Miocene \\
†Zanthopsidae Via, 1959 & Cretaceous (Maastríchtian)-Eocene \\
†New family including Palaeoxanthopsis Beurlen, 1958 & $*$ \\
\hline
\end{tabular}

* indícates families with a fossil record; $†$ indicates extinct families. †See Glaessner, 1969; Müller, 1984; Schweitzer, 2000; Schweitzer \& Feldmann, 2001; Schweitzer, in press.

crabs (Guinot \& Tavares, 2001). The Hexapodidae was formerly a subfamily of the Goneplacidae; these two families are closely related and they appear to have diverged by the Paleocene at the latest. Cretaceous rocks have also yielded a new family that embraces Palaeoxanthopsis; however, the affinities of this family and its relationship to other xanthoid families are not clear. Interestingly, taxa within this new family resemble some members of the Portunidae Rafinesque, 1815, e.g., Rhachiosoma Woodward, 1871, as well as the Xanthoidea; perhaps the common ancestor of the Xanthoidea and Portunoidea may have been morphologically similar to members of this new family.

By the Paleocene, the Zanthopsidae was well established and by the Eocene, four additional families (Table 1) were sufficiently abundant to produce a robust fossil record. Based upon preliminary work, it appears that the Eriphiidae and Panopeidae also have Eocene records (Glaessner, 1969). Clearly, then, many of the extant Xanthoidea had appeared by the Eocene, so that the radiation events must have occurred before that time. Biological and paleontological evidence suggests that the Carpiliidae, Eriphiidae, Pseudoziidae, and Zanthopsidae are closely related (Schweitzer, in press); all have Eocene records. Thus, they must share a common ancestor and must have diverged before that time. However, it is not known when that divergence occurred; it may have been earliest Eocene, for which we have few fossils, and it may have been Paleocene. The paucity of Paleocene rocks and fossils makes it difficult to test this hypothesis, but work is planned by colleagues and myself to investigate Paleocene occurrences in Europe. The timing of appearance and radiations among the other xanthoid families are similarly unknown. Only by placing fossil xanthoids within the appropriate family, using proxy characters, can this problem of timing of divergence and radiation among these families be addressed. Providing a well-documented fossil record for the various xanthoid families will provide a means by which to test biological hypotheses about timing of divergences based upon molecular clock evidence.

\section{Future studies}

The use of proxy characters and other biologically important hard-part characters to evaluate fossil xanthoids may help to clarify the nature and extent of the end-Cretaceous extinction event and the subsequent recovery. It is known already that at least one extant xanthoid family, and possibly two, has a Cretaceous record, suggesting that these animals were minimally affected by the $\mathrm{K} / \mathrm{T}$ event. In addition, several xanthoid families have robust fossil 
records by Eocene time. The question is, when did these xanthoid families appear? Was it during the Paleocene or Eocene? And is the Goneplacidae, or a related lineage, the rootstock of all extant xanthoids, as it has the oldest confirmed fossil record? Was the radiation of the xanthoids in Paleocene or Eocene time a reaction or effect of the $\mathrm{K} / \mathrm{T}$ extinction or was it controlled by other factors? All of these questions are currently under study by Rod Feldmann and myself and will be addressed by using proxy characters as well as by seeking Paleocene exposures.

Another nagging concern is the placement of fossil xanthoids into extant families. Decapod paleontologists have historically placed fossil xanthoids, as well as all decapods, into extant families whenever possible. And this is as it should be; there is no need to create new families that are not warranted by morphological features and differences with extant families. However, the history of biological classification of xanthoids has been contentious, and a superfamily that was once considered to consist of only a few families is now acknowledged to be composed of ten to twelve families. Is there any reason that the fossils should not be similarly diverse? After all, the confirmed xanthoid record extends through $\mathbf{7 0}$ or so million years of time, and it seems likely that there would be some extinct groups. Of course, decapods are clearly conservative evolutionarily, as evidenced by the very fact that Cretaceous fossils can be placed into extant families. The impulse to create new families for difficult taxa must be balanced by a strong commitment to attempting to express biological reality in family-level placement of xanthoids.

Numerous fossil xanthoids have yet to be evaluated in terms of family-level placement. It is suggested here that work on this group proceed by careful study of extant groups, using the robust literature of Davie, Guinot, $\mathrm{Ng}$, and others, to best place fossil xanthoids within a,family. Only then can the evolutionary relationships among this diverse group be explored. This work will lead to increasing utility of fossil xanthoids in determining the phylogenetic and evolutionary history of this important group.

\section{References}

Alcock A. 1898. The family Xanthidae: the Brachyura Cyclometopa, Part I: Material for a Carcinological Fauna of India, No. 3. Jour. Asiatic Soc. Bengal 67(2/1): 67-233.

Alcock A. 1900. Materials for a Carcinological fauna of India. No. 6. The Brachyura Catametopa or Grapsoidea. Jour, Asiatic Soc. Bengal 69(2-3): 279-456.

Bell T. 1863. A monograph of the fossil Malacostracous Crustacea of Great Britain, 2, Crustacea of the Gault and Greensand. Monogr. Palaeontogr. Soc. Lond: 1-40.

Beurlen K. 1958. Contribuição a paleontologia do Estado do Pará, Crostaceos decápodos da Formação Pirabas. Bol. Mus. Paraense Emilio Goeldi, n. s. (Geol.) 5: 2-48, 4 pls.

Dana JD. 1853. On the Classification and Geographical Distribution of Crustacea from the Report on Crustacea of the United States Exploring Expedition, under Captain Charles Wilkes, U.S.N., during the years 1838-1842. Philadelphia: C. Sherman.

Davie PJF. 2002. Crustacea: Malacostraca: Eucarida (Part 2): Decapoda-Anomura, Brachyura. In: Wells A, Houston WWK (eds). Zoological Catalogue of Australia 19.3B: 1-641 Melbourne: CSIRO Publishing.

Glaessner MF. 1969. Decapoda. In: Moore RC (ed.). Treatise on Invertebrate Paleontology, part $R$, Arthropoda 4: R400-R651. Boulderx Geological Society of America/ Lawrence: University of Kansas Press.

Guinot D. 1968a. Recherches préliminaíres sur les groupements naturels chez les Crustacés Décapodes Brachyoures. VI. Les Carpilinae. Bull. Mus. natn Hist. nat. Paris (2)40(1): 320-334.

Guinot D. 1968b. Recherches préliminaires sur les groupements naturels chez les Crustacés Décapodes Brachyoures. V. Établissement d'un caractère évolutif: l'articulation ischio-mérale des chélipèdes, Bull. Mus, natn Hist. nat. Paris (2)40(1): 149-166.

Guinot D. 1977. Propositions pour une nouvelle classification des Crustacés Décapodes Brachyoures. C.R. Acad. Sci. Paris (D)285: 1049-1052.

Guinot D. 1978. Principes d'une classification évolutive des Crustacés Décapodes Brachyoures. Bull. Biol. Fr. Belg. 112(3): 209-292.

Guinot D. 1979. Morphologie et Phylogenèse des Brachyoures. Mém. Mus. nain Hist. nat. Paris, n.s. (A)112: 1-354.

Guinot D, Tavares M. 2001. Une nouvelle famille de Crabes du Crétacé, et la notion de Podotremata Guinot, 1977 (Crustacea, Decapoda, Brachyura). Zoosystema 23: 507 546.

Haan, W. de. 1833-1850. Crustacea. In: Siebold PF de (ed.). Fauna Japonica sive descriptio animalium, quae in itinere per Japoniam, jussu et auspicilis superiorum, qui summum in India Batava Imperium tenent, suscepto, annis 1823-1830 collegit, notis, observationibus et adumbrationibus, illustravit. Lugdunum Batavorum: A. Arnz.

Karasawa $H$, Kato $H$. in press. The family Goneplacídae MacLeay, 1838 (Crustacea: Decapoda: Brachyura): systematics, phylogeny, and fossil records. Paleont. Res. 7(2). 
MacLeay WS. 1838. On the Brachyurous Decapod Crustacea brought from the Cape by Dr. Smith. In: Illustrations of the Annulosa of South Africa; being a portion of the objects of Natural History chiefly collected during an expedition into the interior of South Africa, under the direction of Dr. Andrew Smith, in the years 1834, 1835, and 1836; fitted out by "The Cape of Good Hope Association for Exploring Central Africa." $\times$ 53-71, pl. 2 .

Mantell GA. 1822. The Fossils of the South Downs, or Illustrations of the Geology of Sussex. London: Lupton Relfe.

Martin JW, Davis GE. 2001. An updated classification of the Recent Crustacea. Nat. Hist. Mus. Los Angeles Cty Sci. Series 39: 1-124.

Miers EJ. 1886. Report on the Brachyura collected by $\mathbf{H}$. M. S. Challenger during the years 1873-1876. In: Thomson CW, Murray J (eds). Report of the Scientific Results of the Voyage of H.M.S. Challenger during the years 18731876, Zoology: 1-362. New York: Johnson Reprints.

Milne Edwards A. 1862-1865. Monographie des crustacés de la famille cancériens. Ann. Sci. nat. (Zool.) (4)18(1862): 31-85; 29(1863): 273-324; (5)1(1864): 31-88; 3(1865): 297-351.

Müller P. 1984. Decapod Crustacea of the Badenian. Geol. Hung, Ser, Palaeont. 42: 1-317.

Ng PKL. 1998. Crabs. In: Carpenter KE, Niem VH (eds). The Living Marine Resources of the Western Central Pacific, 2. Cephalopods, crustaceans, holothurians, and sharks: 1046-1155. Rome: FAO.

Ng PKL, Clark P. 2000. The eumedonid file: a case study of systematíc compatibility using larval and adult characters (Crustacea: Decapoda: Brachyura). Invert. Reprod. Developm. 38: 225-252.

Ng PKL, Liao LM. 2002. On a new species of Euryozius Míers, 1886 (Crustacea: Decapoda: Brachyura: Pseudoziidae) from the Philippines, with notes on the taxonomy of the genus, Proc. biol. Soc. Wash. 115: 585-593.

Ortmann A. 1893. Die Decapoden-Krebse der Strassburger Museums, 7. Theil. Abtheilung: Brachyura (Brachyura genuina Boas) 2. Unterabtheilung: Cancroidea, 2. Section: Cancrinea, 1. Gruppe: Cyclometopa. Zool. Jb., Abt. Syst., Geogr. Biol. Thiere 7: 411-495.

Rafinesque CS. 1815. Analyse de la nature, ou tableau ide l'Universe et des corps organisées. Palermo: L'Imprimetie de Jean Barra Vecchia.

Rathbun MJ. 1930. The cancroid crabs of America of the families Euryalidae, Portunidae, Atelecyclidae, Cancridae, and Xanthidae, U.S. Natl Mus, Bull. 152:1-609.

Samouelle G. 1819. The Entomologist's Useful Compendium, or An Introduction to the Knowledge of British Insects, London: Thomas Boys.

Schweitzer CE. 2000. Tertiary Xanthoidea (Crustacea: Decapoda: Brachyura) from the west coast of North America. Jour. Crust. Biol. 20: 715-742.

Schweitzer CE. in press. Utility of proxy characters for classification of fossils: an example from the Xanthoidea (Crustacea: Decapoda: Brachyura). Jour, Paleo, 77.

Schweitzer CE, Feldmann, RM. 2000. New species of calappid crabs from western North America and reconsideration of the Calappidae de Haan sensu lato. Jour. Paleo. 74: 230-246.

Schweitzer CE, Feldmann RM. 2001. Differentiation of the fossil Hexapodidae, Miers, 1886 (Decapoda: Brachyura) from similar forms. Jour. Paleo. 75: 330-345.

Schweitzer CE, Salva EW. 2000. First recognition of the Cheiragonidae Ortmann (Decapoda: Brachyura) in the fossil record and comparison of the family to the Atelecyclidae Ortmann (Decapoda: Brachyura). Jour. Crust. Biol. 20: 285-298.

Schweitzer CE, Feldmann RM, Gonzáles-Barba G, Vega FJ. 2002. New crabs from the Eocene and Oligocene of Baja California Sur, Mexico, and an assessment of the evolutionary and paleobiogeographic implications of Mexican fossil decapods. Paleo. Soc. Mem. 59: 1-43.

Tucker AB, 1998. Systematics of the Raninidae (Crustacea: Decapoda: Brachyura), with accounts of three new genera and two new species. Proc. Biol. Soc. Wash. 111: 320-371.

Tucker AB, Feldmann RM, 1990. Fossil decapod crustaceans from the lower Tertiary of the Prince William Sound region, Gulf of Alaska. Jour. Paleo. 64:409-427.

Vega FJ, Cosma T, Coutiño MA, Feldmann RM, Nyborg TG, Schweitzer CE, Waugh DA. 2001. New middle Eocene decapods (Crustacea) from Chiapas, Mexico. Jour. Paleo. 75: 929-946.

Via L. 1959. Decápodos fósiles del Eoceno español. Bol. Inst. geol. min. España 70: 331-402.

Woodward H. 1871. Notes on some new crustaceans from the lower Eocene of Portsmouth. Q. Jour. Geol. Soc. Lond. (1)27: 90-92, pl. 4 .

Received: 12 March 2003 